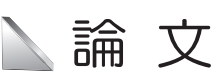

Original Paper

\section{$\mathrm{CO}_{2}$ 地中睁留への適用のための立武岩質岩石の溶解実験 " 一反応実験による溶解速度定数の推定 -}

\title{
Experimental Study on Dissolution of Basaltic Rocks for Underground Sequestration of $\mathrm{CO}_{2}$ - Estimate of Dissolution Rate Constant by Reaction Experiment -
} by Naotatsu SHIKAZONO ${ }^{\mathrm{a}^{*}}$, Hiroyasu HARADA ${ }^{\mathrm{a}}$ and Norio IKEDA ${ }^{\mathrm{b}}$

a. Department of Applied Chemistry, Faculty of Science and Technology, Keio University, 3-14-1, Hiyoshi, Kohokuku, Yokohama, Kanagawa, Japan (*Corresponding author E-mail: sikazono@applc.keio.ac.jp, FAX: 045-566-1551)

b. Mitsubishi Materials Natural Resources Development Corporation, 1-297, Kitabukuro-cho, Omiya-ku, Saitama-shi, Saitama 330-0835, Japan

Dissolution rates of three basaltic rock samples from Japan (Fuji (sample1) and Hachijyojima (sample 2) fresh basaltic rocks, and Kitamatsuura (sample 3) altered basaltic rock) were experimentally determined in a pH range from 3 to 11 at $25^{\circ} \mathrm{C}$. Initial dissolution rate constants are high $(-9.9 \sim-10.4$ in logarithmic unit $)$. It is inferred that the initial dissolution rate is controlled by proton-cation (alkali, alkali earth and aluminium) ion exchange reaction and breakdown of $\mathrm{Si}-\mathrm{O}$ bond in silicate. Long-term dissolution rate constants for $\mathrm{Si}$ determined are $-11.5 \sim-11.8$ (in logarithmic unit) (sample1) and -11.3 -11.8 (sample 2). These values are lower than those for artificial basalt glass previously obtained. The rate constant determined for sample 3 is consistent with those of feldspar previously studied. In future based on the present results on the dissolution rate of basaltic rocks, we will perform calculation on the temporal changes of the amount of carbonates precipitating from groundwater reacting with basaltic host rocks in order to estimate the amount of $\mathrm{CO}_{2}$ fixed by mineral trapping for underground $\mathrm{CO}_{2}$ sequestration in basaltic rock area in Japan.

KEY WORDS: Underground Sequestration of $\mathrm{CO}_{2}$, Basalt, Dissolution, Rate Constant, Mineral Trapping

\section{1. 緒言}

現在，化石燃料の燃焼により発生する $\mathrm{CO}_{2}$ 排出量をいかに減 らすかが緊急の課題となっている。まず，排出削減技術の向上や 社会的な取り組みにより排出量そのものを減らす方法が考えられ る。しかし, $\mathrm{CO}_{2}$ の排出量抑制の難しさの原因として, 化石燃料 使用の結果として必然的に大量の $\mathrm{CO}_{2}$ が発生すること, 現在の 化石燃料の依存体質を容易に変更できないこと，代替エネルギー の開発が経済的，技術的に容易でないこと，また $\mathrm{CO}_{2}$ の発生源 がきわめて多様であることなどがあげられる。化石燃料を使用し ながら $\mathrm{CO}_{2}$ を大気中になるべく排出しない除去システムの確立 が望まれている。そこで考え出されたのが $\mathrm{CO}_{2}$ 地中貯留技術で あり，現在世界的に注目されている。この技術は発電所や工場の ような大規模固定発生源の排ガスから $\mathrm{CO}_{2}$ を分離・回収・輸送し, 地中深部一圧入する技術であり, 即効的, 効率的であるといわれ ている。

この技術は地下 $1,000 \mathrm{~m}$ 程度の採掘済みの油田や天然ガスの貯

*2008 年 5 月 19 日受付 2009 年 2 月 3 日受理

1. 普通会員 慶應義塾大学 理工学部応用化学科 教授

2. 慶應義塾大学 理工学研究科開放環境科学専攻

3. 三菱マテリアル資源開発

[ 著者連絡先 ] FAX: 045-566-1551

E-mail: sikazono@applc.keio.ac.jp

キーワード : $\mathrm{CO}_{2}$ 地中貯留，玄武岩質岩石，溶解，速度定数，釷物卜ラッ ピング
留岩や帯水層の空隙に閉じ込め, $\mathrm{CO}_{2}$ を地下水に溶解させ，さら に貯留岩の上方にあるキャップロックと呼ばれる不透性の岩石に より閉じ込める方法などが考えられている。

地中貯留の利点として圧入した $\mathrm{CO}_{2}$ は一般的に地下 $800 \mathrm{~m}$ 以 深で超臨界流体になり, 体積が地表の $\mathrm{CO}_{2}$ ガスの約 400 分の 1 になるので, 大量の $\mathrm{CO}_{2}$ を貯留可能であることがあげられる。 また, $\mathrm{CO}_{2}$ は地下水に溶解しや寸く（以下の (1) 式), 地表では 水の $20 \sim 30$ 倍の体積の $\mathrm{CO}_{2}$ を溶かし込むことが出来ると考え られる。そして, $\mathrm{CO}_{2}$ が溶解した地下水が周囲の岩石と反応し, さらに $\mathrm{CO}_{2}$ が水に溶解する (以下の (2) 式)。(1)，(2) 式による $\mathrm{CO}_{2}$ のトラッピングを溶解トラッピングという。その後, $\mathrm{CO}_{2}$ が炭酸塩鉱物として, 沈殿し, 地中に固定される (以下の (3) 式)。 この $\mathrm{CO}_{2}$ の固定化を鉱物トラッピングという。以上によるトラ ッピングによって, $\mathrm{CO}_{2}$ を地中に貯留できると考えられている。

$$
\begin{aligned}
& \mathrm{CO}_{2}+\mathrm{H}_{2} \mathrm{O} \rightarrow \mathrm{H}_{2} \mathrm{CO}_{3} \rightarrow \mathrm{H}^{+}+\mathrm{HCO}_{3}{ }^{-} \\
& \mathrm{CaSiO}_{3}+2 \mathrm{CO}_{2}+\mathrm{H}_{2} \mathrm{O} \rightarrow \mathrm{Ca}^{2+}+2 \mathrm{HCO}_{3}{ }^{-}+\mathrm{SiO}_{2} \\
& 2 \mathrm{HCO}_{3}{ }^{-}+\mathrm{Ca}^{2+} \rightarrow \mathrm{CaCO}_{3}+\mathrm{CO}_{2}+\mathrm{H}_{2} \mathrm{O}
\end{aligned}
$$

世界的には，例えばカナダのアルバータ盆地に対して，その地 質, 水, 溶解トラッピングや鉱物トラッピングによる貯留ポテン シャルの評価など様々な角度からの検討がなされている ${ }^{1)} 。 し$ かし, 日本の地質, 地下水水質は海外のものとは異なるのは明ら 
かであり，海外での評価を日本に当てはめるべきではなく，各貯 留地での評価が必要である。

地中貯留法はその場所の地質条件に左右され，また新しい技術 であるだけに地中における $\mathrm{CO}_{2}$ の挙動が必ずしも十分に分かっ ていないなど, 今後に残されている重要な研究課題も多い。わが 国では地中貯留に関する技術の開発に向け，地中貯留のための地 質工学的研究や $\mathrm{CO}_{2}$ の溶解度特性などの研究がはじめられてい るが，トラッピングメカニズムといった基礎的研究は不十分であ る。わが国では溶解トラッピングや鉱物トラッピングに重点を置 いた研究は少ない。例えば，柏木・鹿園 (2003) ${ }^{2)}$ は千葉県房総 半島の第四紀堆積岩 (上総層群) 地域を仮想的 $\mathrm{CO}_{2}$ 地中貯留量地 として, 溶解トラッピングと鉱物トラッピングに関してのシミュ レーションを行った。その結果, 水一岩石反応により炭酸塩鉱物 が生成し，炭素が固定化されることを明らかにした。しかしなが ら,わが国に広く分布する火成岩を用いた研究はなされていない。 わが国での $\mathrm{CO}_{2}$ 地中貯留量についての推定は，いくつかなさ れているが ${ }^{3)}$, 全てが超臨界 $\mathrm{CO}_{2}$ が岩石の空隙を満たすことに よる物理トラッピング (構造トラッピング) によることを仮定し, 推定している。しかしながら，超臨界 $\mathrm{CO}_{2}$ が地下水に接すると 地下水一溶解し, 長期的には炭酸塩鉱物として固定されると考え られる。したがって, 上記の溶解トラッピング, 鉱物トラッピン グによる $\mathrm{CO}_{2}$ 貯留量を推定することが今後必要となる。また, これまでのわが国の $\mathrm{CO}_{2}$ 貯留量の推定は, 海底下堆積岩地域に 対するものであり, 火成岩地域についての推定は今までになされ ていない。一方, 諸外国においては, 玄武岩地域での $\mathrm{CO}_{2}$ 地中 貯留についての研究が進められている。例えば, アメリカ合衆国 のコロンビア川ソレアイト質洪水玄武岩は $200,000 \mathrm{~km}^{2}$ 以上の面 積, 平均 $1,000 \mathrm{~m}$ の厚さもあり, $\mathrm{CO}_{2}$ 地中貯留に有望な地域とい われ, この大陸性ソレアイト質洪水立武岩一地下水反応に対する シミュレーションがなされている ${ }^{4)}$ 。わが国の立武岩質岩石は プレートの沈み込み帯で生成したソレアイト, アルカリ, カルク アルカリ岩系火山岩であり, この島弧性火山岩と大陸性洪水玄武 岩とは岩石学的, 鉱物学的に異なるものである。したがって, そ の水に対する反応性も異なる可能性がある。したがって, もしも わが国の玄武岩質岩石地域で $\mathrm{CO}_{2}$ 地中貯留をする場合は，わが 国の火山岩に関する水に対する反応性に関するデータが必要不可 欠となる。例えば，わが国では，第三紀・第四紀の火成岩が広く 分布する。特に, 陸上, 海底下共に第三紀のグリーンタフ地域が 東北地方を中心に広く分布している。このグリーンタフ地域の火 成岩は, 立武岩と酸性火山岩 (デイサイト・流紋岩)上り主となる。 これらの火成岩が主となる地層は背斜構造とキャップロックから なる地質構造を持たない場合が多いので, わが国ではこれまでほ とんど注目されていなかったと思われるが，これらの構造を持た ない非構造性地域であっても溶解トラッピングメカニズムが効率 的に働くならば， $\mathrm{CO}_{2}$ 地中貯留の有望地域となるかもしれない。 そこで，わが国においても海外でなされているような火成岩地域 での岩石の地下水に対する反応性に関する基礎的研究が望まれる といえる。

\section{2. 研 究目 的}

(1)，(2)，(3) 式からわかるように, 長期的な $\mathrm{CO}_{2}$ の挙動を明ら かにするためには水一岩石反応について考える必要がある。(2) 式から, 母岩の鉱物 (ここでは珪灰石 ) の溶解が速ければ $\mathrm{CO}_{2}$ は 速く $\mathrm{HCO}_{3}$-になることが分かる。そのため母岩となる岩石の溶 解速度定数 $(\mathrm{k})$ は圧入された $\mathrm{CO}_{2}$ の挙動を予測する上でのもっと も重要なパラメーターであるといえる。
日本列島における火成岩の分布面積の割合は $38 \%$ であり，そ の内安山岩・玄武岩・流紋岩で $32 \%$ であり, 玄武岩はわが国で 広く分布する。そこで本研究では, 貯留サイトの母岩として玄武 岩質岩石 ( 後で述べるように岩石学上は玄武岩質安山岩の試料が あるが，ここでは便宜上玄武岩質岩石と呼ぶ）を想定した。これ まで, 玄武岩に関して, 溶液の組成, 温度, $p H$ の違いによる溶 解実験がいくつかなされ, 玄武岩の溶解速度定数が求められてい る ${ }^{5-11)}$ 。しかし, 実験条件がフロースルー型で溶液濃度に関し ての定常状態を観測しており, 短い反応時間についての研究はほ とんどなされていない。また, 酸性条件下での実験が多いが, ア ルカリ性での反応についての実験はなく, 溶解速度定数の $p H$ 依 存性は求められていない。地中貯留では, 地下水に $\mathrm{CO}_{2}$ が溶解 寸ることで初期の $p H$ は 3 程度の酸性条件になる ${ }^{12)}$ 。しかし, この酸性の地下水は周囲の岩石と反応し, $p H$ が上昇する。した がって, 酸性からアルカリ条件下での溶解速度定数のデータが必 要となる。

本研究はバッチ (回分) 型で溶解実験を行った。バッチ型にし たのは, 岩石との反応により放出・消費された溶質は溶液中に濃 集するため, 時間による溶液組成変化, 反応メカニズムの変化を 求められるからである。以上の点を踏まえ, 本研究では, 玄武岩 質岩石の溶解速度定数の決定を主目的にした。

本研究では富士山, 八丈島, 北松浦 (九州) の 3 種類の火山岩 試料の異なる $p H$ の溶液による溶解反応実験を行い, 溶解速度定 数の推定, 溶液組成の時間変化, これらの要因についての考察を 行った。

\section{3. 実 験 方 法}

\section{$3 \cdot 1$ 実験試料}

富士山，八丈島および北松浦 (それぞれ試料 1 , 試料 2, 試料 3 と呼ぶ ) を粉末にし, 蛍光 X 線分析法 $(\mathrm{XRF})$, 粉末 X 線回析 法 (XRD) で分析した。また, 試料 1，2，3 の密度，比表面積を それぞれ電子比重計, 粒度分布測定装置で測定した。なお, 以上 の 3 試料の蛍光 X 線分析によると, 岩石学的には富士山は玄武岩, 八丈島, 北松浦は玄武岩質安山岩である。

\section{$3 \cdot 1 \cdot 1$ 蛍光 $X$ 線分析法 $(\mathrm{XRF})$}

主成分元素組成 $\left(\mathrm{SiO}_{2}, \mathrm{TiO}_{2}, \mathrm{Al}_{2} \mathrm{O}_{3}, \mathrm{\Sigma Fe}\left(\mathrm{FeO}+\mathrm{Fe}_{2} \mathrm{O}_{3}\right), \mathrm{MnO}\right.$, $\mathrm{MgO}, \mathrm{CaO}, \mathrm{Na}_{2} \mathrm{O}, \mathrm{K}_{2} \mathrm{O}, \mathrm{P}_{2} \mathrm{O}_{5}$ ) は蛍光 X 線分析 (XRF) (RIX1000, 理学電気) を用い, ガラスビード法により定量分析を行った。

まず粉末試料をドライオーブンで 24 時間, $110^{\circ} \mathrm{C} て ゙$ 乾燥させ吸 着水を除去した。その後, あらかじめマッフル炉中で焼成してお いた $\left(900^{\circ} \mathrm{C}, 13\right.$ 時間 $)$ 蓋付坩堝に粉末試料約 $0.6 \mathrm{~g}$ を入れ, $900^{\circ} \mathrm{C}$ で 13 時間焼成し, 試料中の揮発性成分 $\left(\mathrm{H}_{2} \mathrm{O}^{(+)}\right.$など $)$を散逸さ せた。この時の粉末試料減量を灼熱減量 (Loss On Ignition, LOI) として重量を測定した。こうして得られた粉末試料 $0.400 \pm$ $0.0002 \mathrm{~g}$ に対して, $\mathrm{Li}_{2} \mathrm{~B}_{4} \mathrm{O}_{7}, 4.000 \pm 0.0002 \mathrm{~g}$ をくく混合し, $1150^{\circ} \mathrm{C}$ で 7 分間溶融後, 冷却させ, 均質なガラスビードを作成し た。それらガラスビードを用いて XRF 分析を行った。標準岩石 試料 ( 産業技術総合研究所地質調查総合センター発行標準岩石試 料) として JB-1b 試料の測定を行った。検量線は標準岩石試料 として JB-3, JH-1, JSy-1, JG-2, JF-1，JGb-2 を用いて作成した。

\section{$3 \cdot 1 \cdot 2$ 粉末 X 線回折法 $(X R D)$}

試料の鉱物同定をXRD (RINT1500, 理学電気) で行った。分 析条件は以下である。i) 管球: $\mathrm{Cu}-\mathrm{K} \alpha$, ii) 電圧 : $40 \mathrm{kv}$, iii) 電流 : $20 \mathrm{~mA}$, iv) スキャンスピード $: 4.00^{\circ} / \mathrm{min}$, v) 測定範囲 : $4^{\circ} \sim 40^{\circ}$ 。

\section{$3 \cdot 1 \cdot 3$ 密度測定}

実験試料の比重を電子比重計 (EW-200SG, アルファーミラー 
A

Table 1 Major element contents of samples studied. 1A: sample 1, 1B: sample 2, 1C: sample 3.

\begin{tabular}{l|l|l|l|l|l|l|l|l|l|l|l|l}
\hline Oxides & $\mathrm{SiO}_{2}$ & $\mathrm{TiO}_{2}$ & $\mathrm{Al}_{2} \mathrm{O}_{3}$ & $\mathrm{Fe}_{2} \mathrm{O}_{3}{ }^{*}$ & $\mathrm{MnO}$ & $\mathrm{MgO}$ & $\mathrm{CaO}$ & $\mathrm{Na}_{2} \mathrm{O}$ & $\mathrm{K}_{2} \mathrm{O}$ & $\mathrm{P}_{2} \mathrm{O}_{5}$ & LOI & Total \\
\hline $\mathrm{wt} \%$ & 51.07 & 0.44 & 16.90 & 11.64 & 0.17 & 5.06 & 9.70 & 2.62 & 0.75 & 0.27 & 0.01 & 99.82 \\
\hline
\end{tabular}

B

\begin{tabular}{l|l|l|l|l|l|l|l|l|l|l|l|l}
\hline Oxides & $\mathrm{SiO}_{2}$ & $\mathrm{TiO}_{2}$ & $\mathrm{Al}_{2} \mathrm{O}_{3}$ & $\mathrm{Fe}_{2} \mathrm{O}_{3}{ }^{*}$ & $\mathrm{MnO}$ & $\mathrm{MgO}$ & $\mathrm{CaO}$ & $\mathrm{Na}_{2} \mathrm{O}$ & $\mathrm{K}_{2} \mathrm{O}$ & $\mathrm{P}_{2} \mathrm{O}_{5}$ & LOI & Total \\
\hline wt $\%$ & 53.87 & 1.67 & 13.72 & 14.66 & 0.24 & 3.24 & 8.24 & 2.54 & 0.54 & 0.26 & 0.00 & 98.98 \\
\hline
\end{tabular}

C

\begin{tabular}{l|l|l|l|l|l|l|l|l|l|l|l|l}
\hline Oxides & $\mathrm{SiO}_{2}$ & $\mathrm{TiO}_{2}$ & $\mathrm{Al}_{2} \mathrm{O}_{3}$ & $\mathrm{Fe}_{2} \mathrm{O}_{3}{ }^{*}$ & $\mathrm{MnO}$ & $\mathrm{MgO}$ & $\mathrm{CaO}$ & $\mathrm{Na}_{2} \mathrm{O}$ & $\mathrm{K}_{2} \mathrm{O}$ & $\mathrm{P}_{2} \mathrm{O}_{5}$ & LOI & Total \\
\hline wt $\%$ & 52.58 & 1.44 & 15.46 & 7.79 & 0.11 & 2.94 & 6.82 & 3.35 & 2.02 & 0.33 & 6.23 & 99.06 \\
\hline
\end{tabular}

Table 2 Main constituent minerals in the samples studied.

\begin{tabular}{l|l}
\hline Sample 1 & feldspar, pyroxene, olivine, glass \\
\hline Sample 2 & feldspar, pyroxene, olivine, glass \\
\hline Sample 3 & feldspar, pyroxene, olivine, carbonate(calcite) \\
\hline
\end{tabular}

ジュ（株））で測定した。測定用媒体は水を用い，測定物質の比 重=測定物質の密度とみなせる ( 測定時の水の温度をあらかじめ 設定しておくことで, 測定物質は $4{ }^{\circ} \mathrm{C}$ 水の中で測定した比重值 に補正される)。

測定方法は試料を比重容器の上に置き空中重量を記録させた。 その後, 測定試料を水約 $70 \%$ とアルコール約 $30 \%$ を入れたビー カーに入れ，試料の付着物や油を取り除いた。そして比重を測定 した。

\section{$3 \cdot 1 \cdot 4$ 比表面積測定}

レーザー回折／散乱式粒度分布測定装置（堀場製作所，LP-920) を用いて反応前, 反応後の試料の比表面積を測定した。溶媒には 水を用い光軸の初期設定，ブランク測定，試料測定をした。この 装置は相対屈折率によって比表面積の值が大きく異なる。水の屈 折率は 1.33 , 玄武岩の屈折率は 1.50 であるので, 相対屈折率は 1.12 となる。

\section{$3 \cdot 2$ 溶解実験}

Ar ガスで脱気した蒸留水, 塩酸及び炭酸ナトリウムを用いて $p H(=3,5,7,9,11)$ の異なる 5 種類の溶液を調製した。ポリ製の反応 容器に調製した溶液 $70 \mathrm{ml}$ と試料, 酸性及び中性溶液には $0.7 \mathrm{~g}$, アルカリ性溶液には $1.5 \mathrm{~g}$ ずつ入れ $25^{\circ} \mathrm{C} の$ 恒温槽に入れた。反応 時間は $1,5,10,30$ 分 (試料 1 のみ)，1，3，5，10 時間， 1，3， 5, 10，15，20，30 日である。それぞれ反応終了後, 吸引ろ過で 試料と溶液を分離した。

\section{$3 \cdot 3$ 分析}

溶液の $p H$ を $p H$ メーター(ポータブル $p H$ 計 HM-20P, HM$21 \mathrm{P}$, 東亜ディーケーケー), 全炭酸濃度を炭酸ガス測定器 (Ti-9004, 東亜化学研究所), 元素濃度 ( $\mathrm{Si}, \mathrm{Al}, \mathrm{Ca}, \mathrm{Mg}, \mathrm{Fe}$, $\mathrm{Na}, \mathrm{K}, \mathrm{Mn}$ ) をICP-AES (ICAP-757v, Nippon Jarrel Ash, 卓上型 ICP 発光分光分析装置 SPS7800, セイコーインスツル株式会社) で測定した。

\section{4. 実験 結 果}

4. 1 実験試料

$4 \cdot 1 \cdot 1 \quad \mathrm{XRF}$

試料 1,2 及び 3 の分析結果を Table 1 に示した。なお, Table
Table 3 Density and specific surface area of the samples studied.

\begin{tabular}{c|c|c}
\hline & $\begin{array}{c}\text { Density } \\
{\left[\mathrm{g} / \mathrm{cm}^{3}\right]}\end{array}$ & $\begin{array}{c}\text { specific surface area } \\
{\left[\mathrm{cm}^{2} / \mathrm{cm}^{3}\right]}\end{array}$ \\
\hline Sample 1 & 2.64 & 10621 \\
\hline Sample 2 & 2.51 & 18604 \\
\hline Sample 3 & 2.70 & 31859 \\
\hline
\end{tabular}

1 で示した值は, LOI ( 灼熱減量) を求めて測定結果を補正した 值である。

\subsection{2 XRD}

XRD で求められた試料 1,2 および 3 の典型的な構成物質を Table 2 に示した。

試料 $1 ， 2$ はほとんど構成鉱物に違いはなく, ガラスが含まれ ている。これらには変質鉱物 (粘土鉱物, 炭酸塩鉱物等) は含ま れておらず，新鮮な岩石試料である。試料 3 は試料 1,2 と比心゙ ガラスは存在しないが, 炭酸塩鉱物 (方解石) がある。これは, この試料が变質作用を受け, 炭酸塩鉱物が生成されたことを示し ている。なお，偏光顕微鏡観察によってもこれらの鉱物種 (炭酸 塩鉱物, 輝石, オリビン, 火山ガラス等) を確認した。

\section{$4 \cdot 1 \cdot 3$ 密度と比表面積}

試料 1,2 および 3 の密度と比表面積は, Table 3 に示した。

\section{$4 \cdot 2$ 溶解実験}

$4 \cdot 2 \cdot 1 \mathrm{pH}$

$p H$ の時間変化を Figs. 1A ( 試料 1), B ( 試料 2), C ( 試料 3) に示す。試料 1,2 は初期 $p H=3,11$ で増減の変化は小さく, 初 期 $p H=5 ， 7 ， 9$ では増減するが，時間の増加とともに約 8 に近づ いていくように見られる。試料 3 は初期 $p H=3$ で反応後すぐに $p H$ が増加している。これは炭酸塩鉱物の溶解 $\left(\mathrm{CaCO}_{3}+2 \mathrm{H}^{+} \rightarrow\right.$ $\left.\mathrm{Ca}^{2+}+\mathrm{H}_{2} \mathrm{CO}_{3}\right)$ により $p H$ が増加していると考えられる。アルカリ 性側では変化が小さいことからも炭酸塩鉱物の溶解によると考えら れる。

\section{$4 \cdot 2 \cdot 2$ 元素濃度}

(1) $\mathrm{Si}$ 濃度 Figs. 2A (試料 1), B ( 試料 2), C ( 試料 3) に $\mathrm{Si}$ 濃度の時間変化を示す。各試料の全 $p H$ で時間に対し増加し, 徐々に一定值に達している。その值の違いは初期 $p H$ で異なって おり，試料 1,2 では $p H$ が低い，もしくは高いほど高い。試料 3 は酸性及び中性付近ではあまり変化がみられないが, 初期 $p H=11$ の実験の $p H$ はまだ増加するかもしれない。試料 3 の初期 $p H=3$ の実験では 1 時間後には $p H$ はほぼ 7 になった。初期 $p H$ が 3 で も主として中性付近での溶解と考えられるため, 試料 1,2 と比べ, 濃度に大きな差が出なかったと考えられる。 

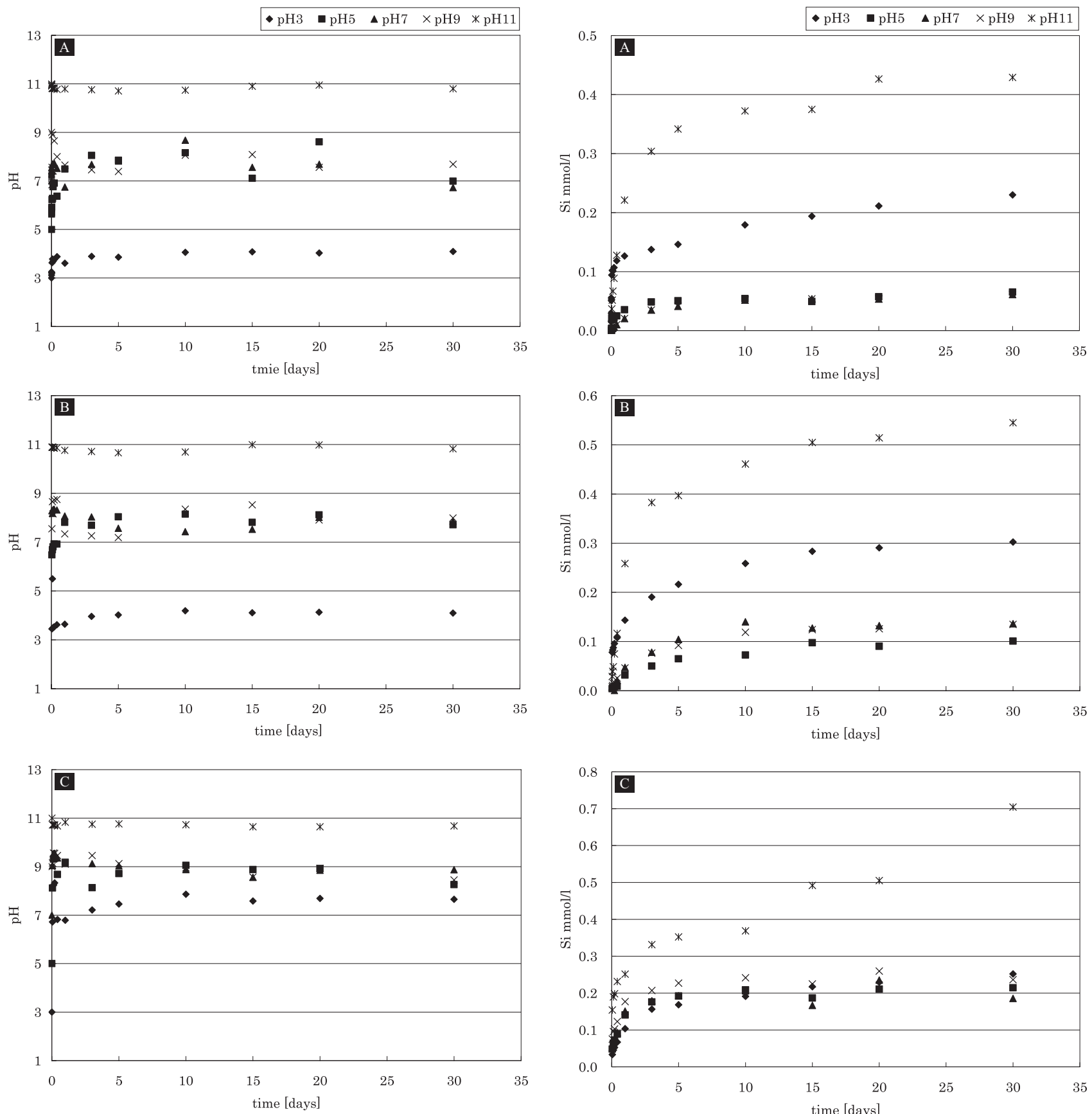

Fig.1 The change of $p H$ with time A: sample1, B: sample 2, C: sample 3.

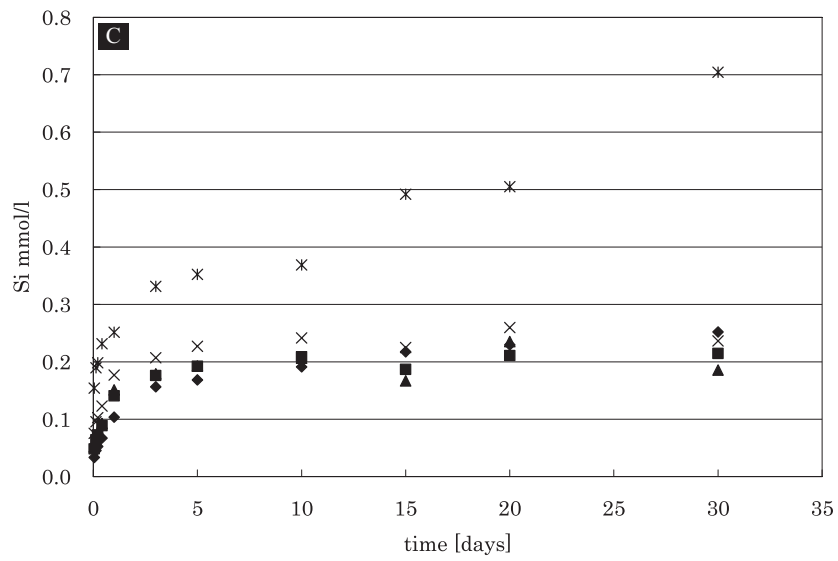

Fig.2 The change of Si concentration with time A: sample 1, B: sample 2, C: sample 3.

(2) Al 濃度 Figs. 3A ( 試料 1), B ( 試料 2) , C ( 試料 3) に $\mathrm{Al}$ 濃度の時間変化を示す。試料 1,2 の全初期 $p H$ で時間に対し 増加し, 一定值に達している。その傾向は $\mathrm{Si}$ 濃度のものと似て いる。試料 3 は試料 1,2 と異なり, 中性近くの $p H$ で濃度が高く, $p H 3$ では低い。また, 濃度オーダーは試料 1,2 と試料 3 で一桁 異なっている。

（3） Ca 濃度 Figs. 4A (試料 1), B ( 試料 2)，C（試料 3) に $\mathrm{Ca}$ 濃度の時間変化を示す。全試料の全 $p H$ で時間に対し増加し, 一定值に達している。その傾向は試料 1,2 の $\mathrm{Si}, \mathrm{Al}$ 濃度のもの と似ている。試料 3 は試料 1,2 と比べ濃度が高い。これは炭酸 塩鉱物の溶解による結果と考えられる。

(4) $\mathrm{Mg}$ 濃度 $\mathrm{Mg}$ 濃度は全試料の全 $p H$ で時間に対し増加, 一定值に達している (Fig. 5A, B, C)。傾向は Ca 濃度と似ている。

また試料 3 は試料 1,2 と比べ濃度が高い。

(5) K 濃度 Figs. 6A ( 試料 1)， B ( 試料 2)，C（試料 3) に $\mathrm{K}$ 濃度の時間変化を示す。試料 1,2 は $p H=3,11$ で短期間です ぐに一定值になった。そして中性付近ではほとんど溶解しなかっ た（もしくは未検出）。試料 3 は全 $p H$ で時間と共に増減している。

(6) $\mathrm{Na}$ 濃度 Figs. 7A ( 試料 1), B ( 試料 2), C ( 試料 3) に $\mathrm{Na}$ 濃度の時間変化を示す。アルカリ性で炭酸ナトリウムを用い たため, 酸・中性のみのデータとなった。全試料の全 $p H$ で時間 に対し増加し, 一定值に達している。全試料でほぼ同じ傾向を示 し, 濃度オーダーも同じとなった。試料 $1 ， 2$ はほぼ同様の溶解 傾向を示した。対して試料 3 は試料 1,2 とは異なる溶解傾向を 示した。これらは構成物質で試料 $1 ， 2$ にはガラス成分が，試料 3 では炭酸塩鉱物があり, この違いが溶解傾向の大きな一要因と 

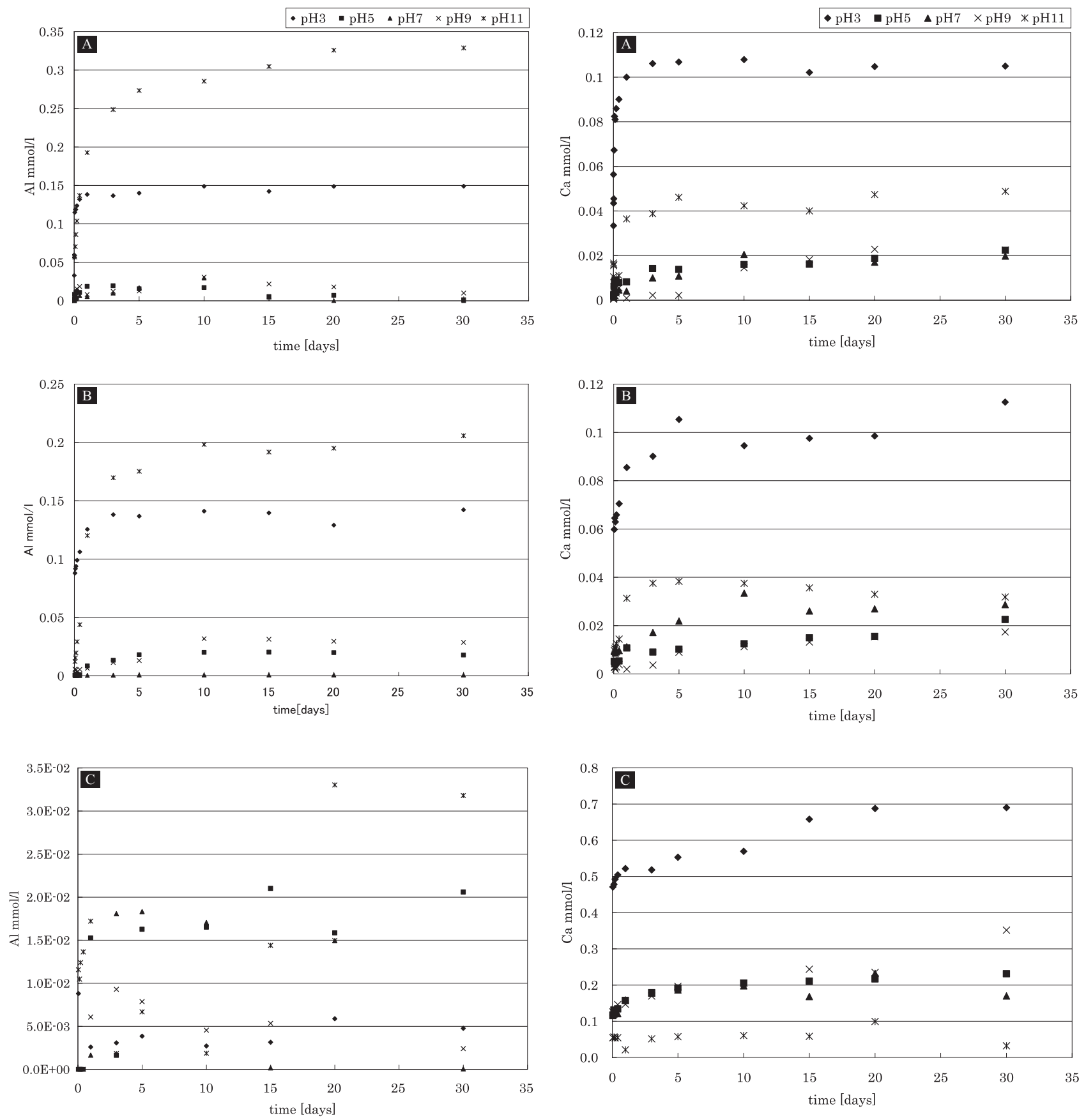

Fig.3 The change of Al concentration with time. A: sample 1, B: sample 2, C: sample 3.

考えられる。

5. 考察

\section{$5 \cdot 1$ 溶解メカニズム}

Figs.1-7 に示すように急速な初期溶解がみられる。この理由と して,（1）試料粉砕後に表面に付着している細かい粒子が高い表 面自由エネルギーを持ち, 大きな粒子よりももっと急速に溶解す ること, (2) 粉砕時における表面の崩壊により, もっと急速に溶 解する無秩序層ができること, そして, (3) 元素の急速な放出は, 非化学量論的組成をもつ薄い定常状態表面層が存在する結果であ る,があげられている13)。

試料 $1 ， 2$ を見ると，酸性および中性で，ほとんどの元素が短

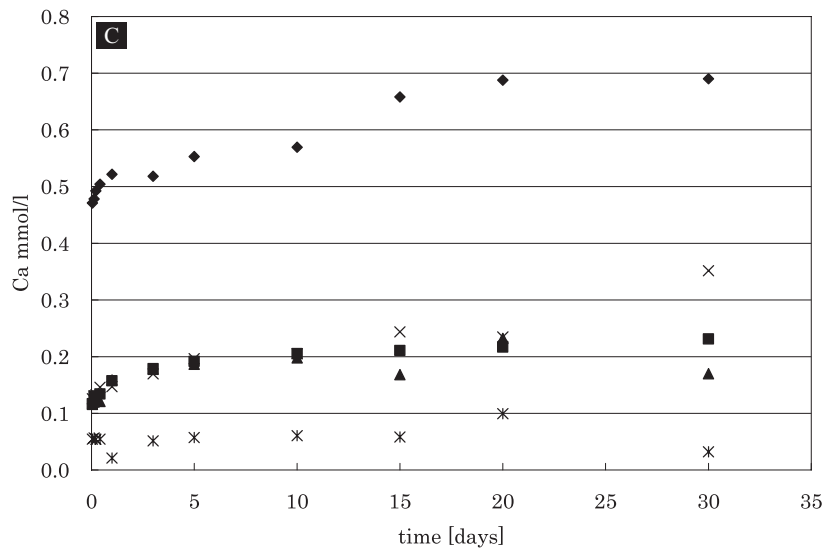

Fig.4 The change of Ca concentration with time. A: sample 1, B: sample 2, C: sample 3.

時間で濃度がある程度高くなっている。さらにくわしく見ると， 1 価陽イオン $\left(\mathrm{Na}^{+}, \mathrm{K}^{+}\right), 2$ 価陽イオン $\left(\mathrm{Ca}^{2+}, \mathrm{Mg}^{2+}\right), \mathrm{Al}$ そし て Si の順に濃度の増加傾向の時間依存性が小さくなっている。 溶解の順序としては, 1 価陽イオン $\rightarrow 2$ 価陽イオン $\rightarrow \mathrm{Al} \rightarrow \mathrm{Si}$ の 順序であることが推測される。また, 試料 3 でも短時間で 1,2 価陽イオンはある程度高くなっている。しかし試料 1,2 と異な り $\mathrm{Al}$ が全 $p H$ でほとんど溶解されず, $\mathrm{Ca}, \mathrm{Mg}$ は試料 1,2 と比 べ濃度が 1 桁高くなっている。 $\mathrm{Al}, \mathrm{Ca}$ そして $\mathrm{Mg}$ の溶解の傾向 から, 試料 3 は炭酸塩鉱物と珪酸塩鉱物の溶解が主な反応入カニ ズムであると考えられる。立武岩質ガラスや長石などの溶解につ いては, Si 種の放出がガラスおよび鉱物溶解の律速になってい るといわれている。ガラスおよび珪酸塩鉱物の溶解メカニズムは Oelkers and Gislason (2001) ${ }^{10)}$ によってまとめられており，アルカ 

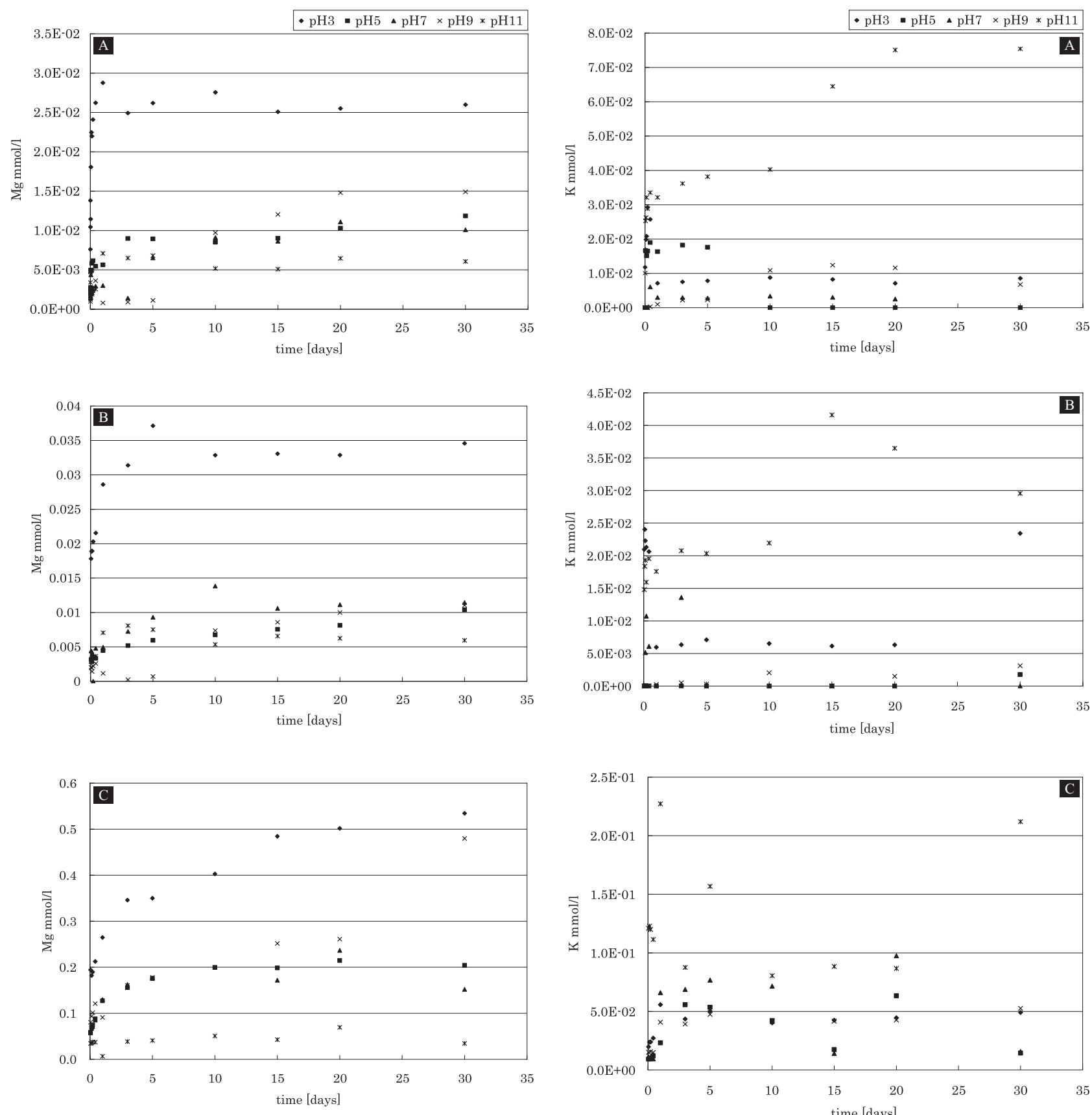

Fig.5 The change of $\mathrm{Mg}$ concentration with time. A: sample 1, B: sample 2, C: sample 3.

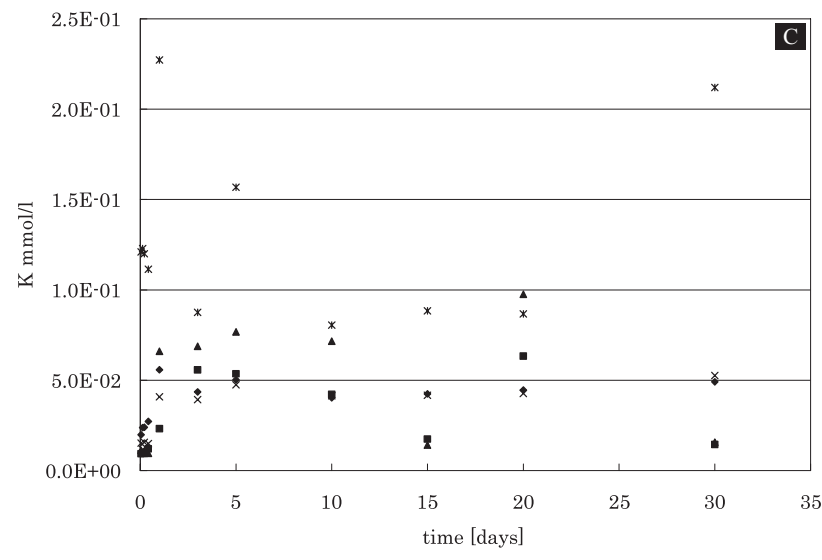

Fig.6 The change of $\mathrm{K}$ concentration with time. A: sample 1, B: sample 2, C: sample 3.

リ元素イオン $-\mathrm{H}^{+}$交換, $\mathrm{Ca}^{2+}-\mathrm{H}^{+}$交換, $\mathrm{Mg}^{2+}-\mathrm{H}^{+}$イオン交換, $\mathrm{Al}^{3+}-\mathrm{H}^{+}$交換, $\mathrm{Si}-\mathrm{O}$ 結合のブレーキングの順序でおこるといわ れている。

玄武岩質ガラスの初期の溶解は，アルカリ元素 $(\mathrm{Na}, \mathrm{K})$ そして アルカリ土類元素 $(\mathrm{Ca}, \mathrm{Mg})$ の優先的な溶出によりおこり，ガラス 表面から金属/プロトン交換反応によって溶脱表面層が形成する。 この溶脱表面層は, 溶脱表面層のガラスモディファイング元素の 溶解が, 溶脱表面層自体の溶解速度と等しくなるまで大きくなる。 よって長期の溶解は化学量論的である。長期的な玄武岩質ガラスの 溶解速度は, $\mathrm{Si} / \mathrm{Al} / \mathrm{Fe}$ (III) 溶脱層の溶解速度か, ガラス中のモディフ アイングカチオンの溶解速度のどちらかと等しいといわれている13)。

\section{$5 \cdot 2$ 玄武岩質岩石の溶解速度定数の推定}

鉱物の溶解速度は以下の (1) 式で表される。

$$
\frac{d C i}{d t}=k\left(\frac{A}{M}\right)\left(1-\left(\frac{C_{i}}{C e q}\right)^{n}\right)
$$

ここで, $C_{i}$ : i 成分の濃度 $\left[\mathrm{mol} / \mathrm{kgH}_{2} \mathrm{O}\right], k$ : 溶解速度定数 $[\mathrm{mol} /$ $\mathrm{m}^{2} / \mathrm{s}$ ], $t$ : 時間 $[\mathrm{s}], n$ : 反応次数, $C_{e q}: \mathrm{i}$ 成分の平衡濃度 $[\mathrm{mol} /$ $\left.\mathrm{kgH}_{2} \mathrm{O}\right], A / M$ : 鉱物表面積 / 水の質量 $\left[\mathrm{m}^{2} / \mathrm{kgH}_{2} \mathrm{O}\right]$ 。

玄武岩質ガラスは多成分からなり，これらのすべての成分を考 慮した溶解・沈殿反応速度定数を求めることは難しい。したがっ て, ここで求めた $k$ はみかけの溶解速度定数である。5-3 で求め る $p H$ に依存した溶解速度定数 $\left(k_{\mathrm{H}^{+}}, k_{\mathrm{OH}}{ }^{-}\right)$はみかけの溶解速度 定数である。

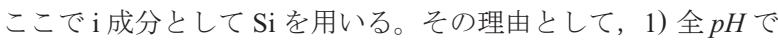



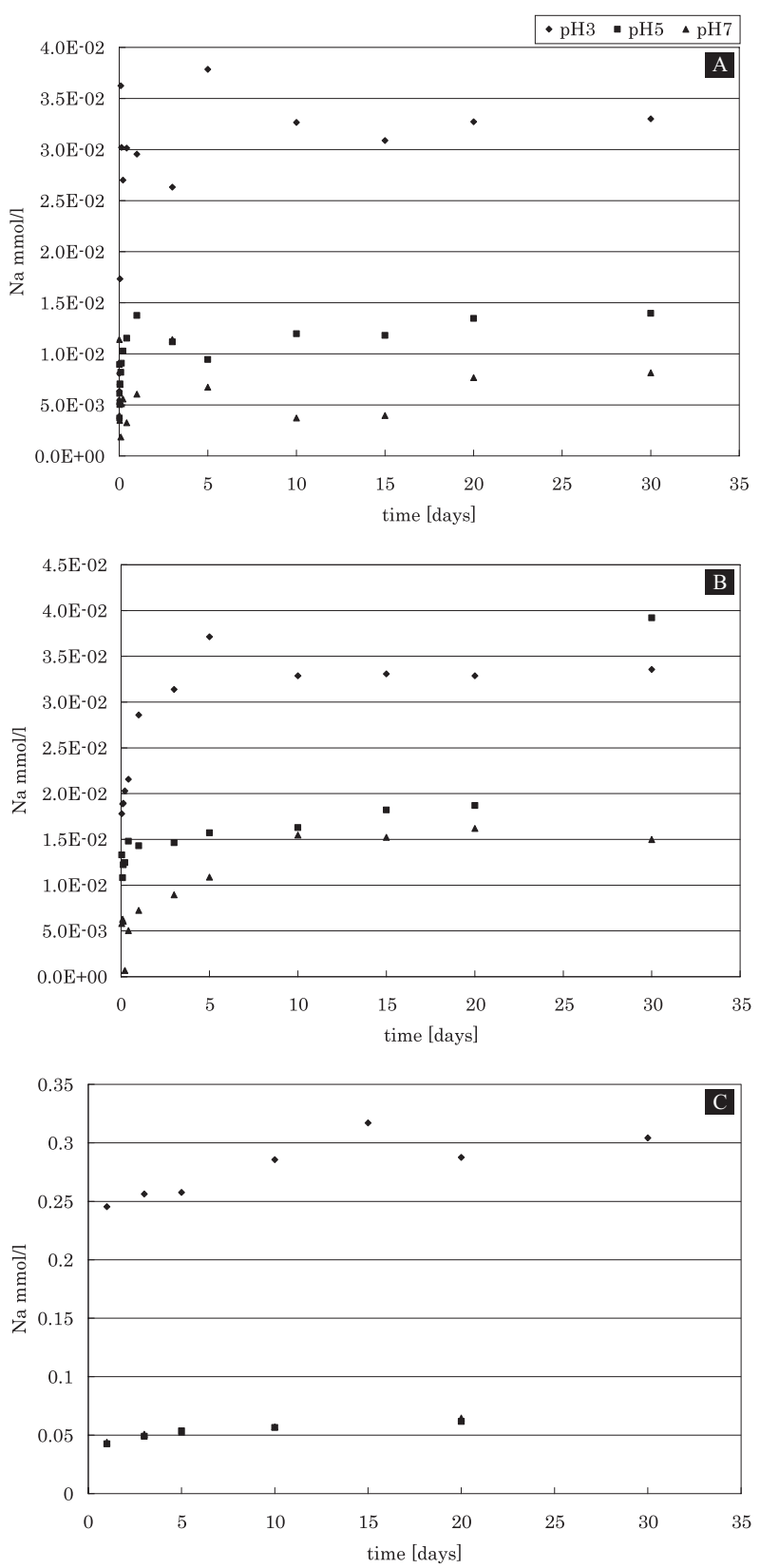

Fig.7 The change of Na concentration with time. A: sample 1, B: sample 2, C: sample 3 .

時間に対して Si 濃度が増加している，2）Si は鉱物やガラスを構 成するフレームワークの一部である，3）溶解反応により水溶液 中の $\mathrm{Si}$ 濃度が決められる。

$A / M$ は比表面積, 密度と実験条件から求められた。密度は試料 によって異なり，比表面積も反応によって変化する。

溶解速度定数を以下の方法で求めた。

初期の溶解では $C_{e q} \gg C_{i}$ であり, $\left(C_{e q}-C_{i}\right) / C_{e q}$ は 1 とする

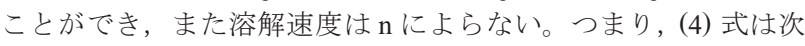
のように表せる。

$\frac{d C_{i}}{d t}=k\left(\frac{A}{M}\right)$

$C_{i}=k\left(\frac{A}{M}\right) t$

全試料の全 $p H$ で初期溶解速度定数を（3）式から最小二乗法を

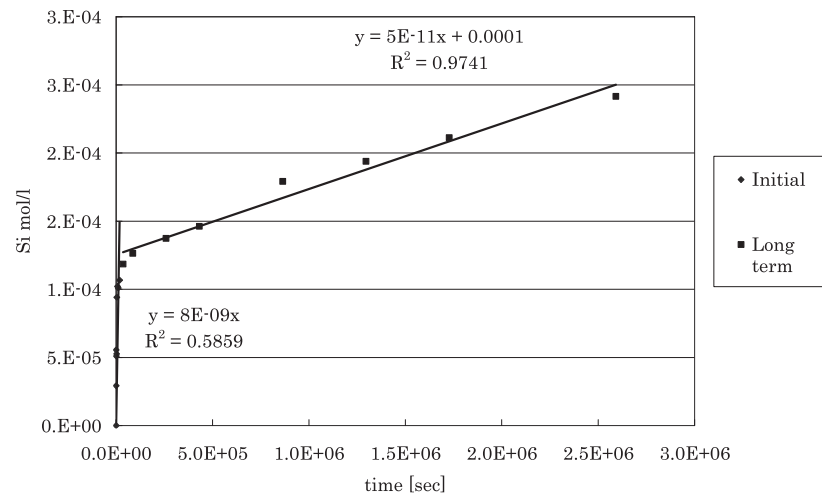

Fig.8 The change of Si concentration with time, (sample 1, initial $p H=3$ ) and least square fitting line for short-period and long-period

用いて求め, 長期溶解速度定数も最小二乗法を用いた。Fig.8に 試料 1 の初期 $p H=3$ の $\mathrm{Si}$ 濃度の経時変化を示した。ここで初期 溶解と長期溶解の傾きを示した。

傾きから，それぞれ $A / M$ を考慮し，各 $p H$ に対する初期・長期 の溶解速度定数を求めた。試料 1,2 は初期溶解速度の $A / M$ は実 験前の值を用いた。試料 3 の $A / M$ は反応後すぐに大きな変化が あるので, 10 時間までの平均值を用いて計算した。長期溶解速 度の $A / M$ は全試料で 15,30 日後の平均值を用い計算した。その 結果を Table 4 に示す。この結果より明らかなように初期溶解速 度定数と長期溶解速度定数には大きな違いがみられ，このことよ り初期と長期で溶解メカニズムが異なることを示していると考え られる。初期溶解速度に対しては, $\mathrm{H}^{+}$一陽イオン (アルカリ, アルカリ土類元素 ) のイオン交換, $\mathrm{Si}-\mathrm{O}$ ブレーキング, 超細 粒子の溶解反応がきくと言われているが 10)，それ程明らかにな っているとは言えず，今後の検討を要する。一方， $\mathrm{CO}_{2}$ 地中貯留 に伴う鉱物トラッピングは長期的現象であるので，この長期溶解 反応速度定数を用いて，シミュレーションを行い，鉱物トラッピ ングによる $\mathrm{CO}_{2}$ 固定化率を計算によって求めることが可能になる。

次に, 試料の違いによる溶解速度の違いをみてみる。Table 4 に示すように, 初期溶解速度定数, 長期溶解速度定数共に試料に よる違いは認められない。ただし, $p H=11$ の溶解速度定数につい ては, 試料 3 は試料 1,2 に比べてやや小さい。 $\mathrm{CO}_{2}$ 地中貯留に おいて, $\mathrm{CO}_{2}$ 圧入後の地下水の $p H$ は一般的には酸性一中性が考 えられるので ${ }^{4)}$, 試料 $1,2,3$ の違いによる溶解速度定数には 違いがないと考えて良いであろう。前述の如く, 試料 3 はカルサ イトを含み, やや変質作用を受けているが，試料 1,2 は変質作 用をほとんど受けていない。

全試料で溶解速度定数は $p H$ に依存しているのが確認された。 試料 3 は試料 $1 ， 2$ に比べると $p H$ に依存していないように見える が，これは初期 $p H 3$ の実験では炭酸塩鉱物の溶解によって 1 時間 後には $p H 7$ まで上昇したためである。このため酸性溶液というよ りも結果として中性溶液での溶解実験になったと考えられる。

次に本実験から求められた試料の溶解速度定数とこれまでの実 験により求められた值を比べる。試料 1,2 は玄武岩ガラスの溶 解と考え, これまでの報告例と比較する。これまでに求められた 玄武岩ガラスの溶解速度定数 (対数值) は $25^{\circ} \mathrm{C}$, 中性条件で, 初 期 $=-9.13\left[\log \mathrm{Si} \mathrm{mole} / \mathrm{m}^{2} \cdot \mathrm{s}\right]^{5)}$, 長期 $=-10.5\left[\log\right.$ Si mole $/ \mathrm{m}^{2}$. s] 5) である。本実験では, 試料 $1:$ 初期 $=-9.91 \sim-10.24$, 長期 $=-11.5 \sim-11.8$, 試料 2 : 初期 $=-10.1 \sim-10.4$, 長期 $=-11.3$ 〜-11.8 となり, 1 桁程度小さい值となった。

また, 試料 3 は長石の溶解と考えた。本実験では, 中性付近： 

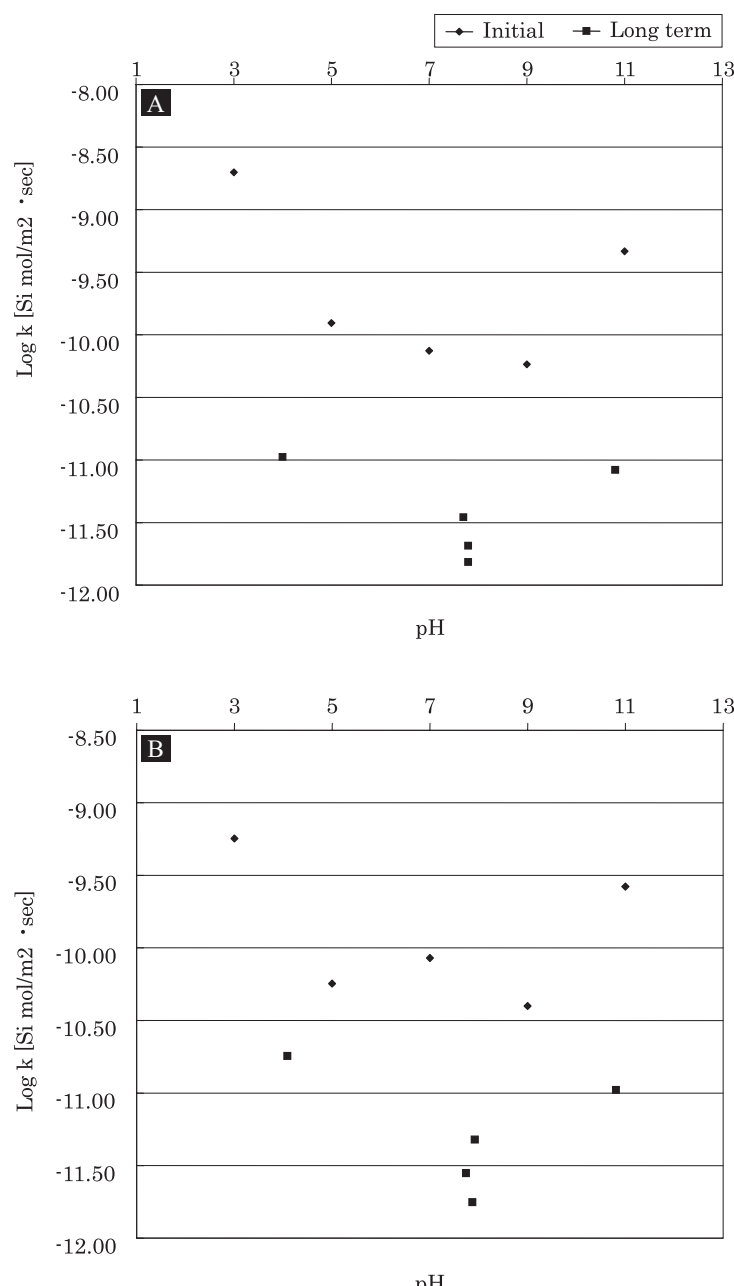

$\mathrm{pH}$

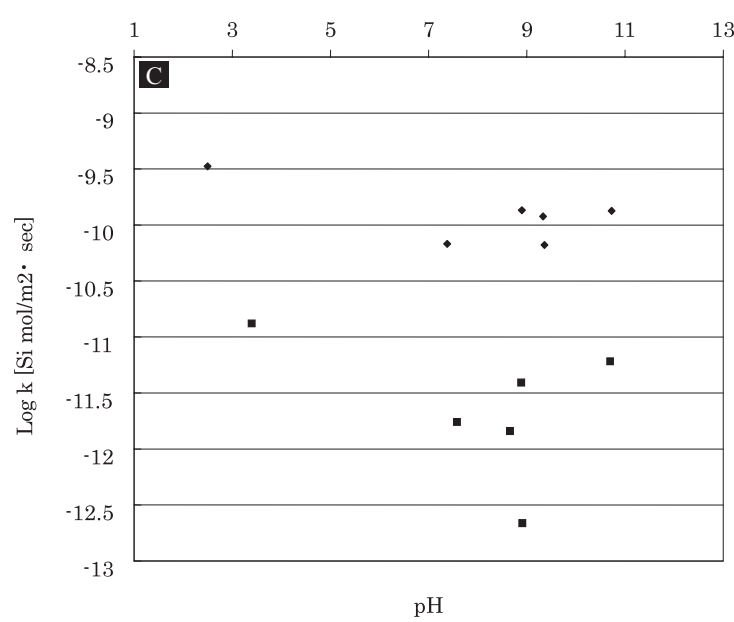

Fig.9 Dependency of rate constant on $p H$. A: sample 1, B: sample 2, C: sample 3.

初期 $=-9.9$, 長期 $=-10.9 \sim-11.8$, アルカリ性 : 初期 $=-9.9$ $\sim-10.2$, 長期 $=-10.5 \sim-12.7\left[\mathrm{Log} \mathrm{Si} \mathrm{mole} / \mathrm{m}^{2} \cdot \mathrm{s}\right]$ となり, こ れまでの結果 ${ }^{16)}$ とほぼよい一致を見せた。

過去の報告例や本実験で求めた溶解速度定数の異なる原因の一 つとして, 今回の実験では天然ガラスを用いたが, 従来の研究で は人工ガラスを用いた点があげられる。

Shiraki and Iiyama（1990） ${ }^{17)}$ は, 天然と人工の流紋岩ガラスと
Table 4 Dissolution rate constant $\left(k_{\mathrm{H}}{ }^{+}, k_{\mathrm{OH}}{ }^{-}\right)$(in logarithmic unit) and $A / M$ for A

\begin{tabular}{c|c|c|c|c|c}
\hline \multicolumn{2}{c|}{$p H$} & \multicolumn{2}{c|}{$A / M\left[\mathrm{~m}^{2} / \mathrm{kg} \mathrm{H}_{2} \mathrm{O}\right]$} & \multicolumn{2}{c}{$\begin{array}{c}\text { Rate constant } \\
\text { Log } k\left[\mathrm{Si} \mathrm{mol} / \mathrm{m}^{2} / \mathrm{sec}\right]\end{array}$} \\
\hline Initial & Final & Initial & Long term & Initial & Long term \\
\hline 3 & 4.00 & 4.02 & 4.71 & -8.70 & -10.98 \\
\hline 5 & 7.80 & 4.02 & 4.60 & -9.91 & -11.81 \\
\hline 7 & 7.69 & 4.02 & 2.83 & -10.13 & -11.46 \\
\hline 9 & 7.71 & 8.62 & 11.00 & -10.24 & -11.69 \\
\hline 11 & 10.81 & 8.62 & 9.54 & -9.33 & -11.08 \\
\hline
\end{tabular}

B

\begin{tabular}{c|c|c|c|c|c}
\hline \multicolumn{2}{c|}{$p H$} & \multicolumn{2}{c|}{$A / M\left[\mathrm{~m}^{2} / \mathrm{kg} \cdot \mathrm{H}_{2} \mathrm{O}\right]$} & \multicolumn{2}{c}{$\begin{array}{c}\text { Rate constant } \\
\text { Log } k\left[\mathrm{Si} \mathrm{mol} / \mathrm{m}^{2} / \mathrm{sec}\right]\end{array}$} \\
\hline Initial & Final & Initial & Long term & Initial & Long term \\
\hline 3 & 4.09 & 7.05 & 2.77 & -9.25 & -10.74 \\
\hline 5 & 7.92 & 7.05 & 4.19 & -10.25 & -11.32 \\
\hline 7 & 7.74 & 7.05 & 7.13 & -10.07 & -11.55 \\
\hline 9 & 7.87 & 15.10 & 11.31 & -10.40 & -11.75 \\
\hline 11 & 10.81 & 15.10 & 9.52 & -9.58 & -10.98 \\
\hline
\end{tabular}

C

\begin{tabular}{c|c|c|c|c|c}
\hline \multicolumn{2}{c|}{$p H$} & \multicolumn{2}{c|}{$A / M\left[\mathrm{~m}^{2} / \mathrm{kg} \mathrm{H}_{2} \mathrm{O}\right]$} & \multicolumn{2}{c}{$\begin{array}{c}\text { Rate constant } \\
\text { Log } k\left[\mathrm{Si} \mathrm{mol} / \mathrm{m}^{2} / \mathrm{sec}\right]\end{array}$} \\
\hline Initial & Final & Initial & Long term & Initial & Long term \\
\hline 1.85 & 3.4 & 12.07 & 20.21 & -9.48 & -10.88 \\
\hline 3 & 7.38 & 12.07 & 23.43 & -10.17 & -11.76 \\
\hline 5 & 8.9 & 12.07 & 19.07 & -9.87 & -11.84 \\
\hline 7 & 9.33 & 12.07 & 13.54 & -9.92 & -11.41 \\
\hline 9 & 9.36 & 25.86 & 47.67 & -10.18 & -12.66 \\
\hline 11 & 10.73 & 25.86 & 34.41 & -9.88 & -11.22 \\
\hline
\end{tabular}

水溶液反応実験を高温 $\left(200 \sim 300^{\circ} \mathrm{C}\right)$ で行い, ガラスと水溶液間 の $\mathrm{K}^{+}, \mathrm{Na}^{+}$の分配比を求め, それらが大きく異なることを示した。 したがって, 天然ガラスと人工ガラスの溶解速度も大きく異なる ことも考えられる。この他の原因として, 玄武岩質ガラスの表面 積の変化, 玄武岩質ガラス組成の相違, ガラス表面の変化, ガラ ス組成の相違などがあげられ，これらについての今後の詳しい検 討が必要である。

なお, 次の $5 \cdot 3$ で述べるように, 溶解速度定数は $p H$ に依存 寸るので, 溶解速度定数を $p H$ の関数として示す必要がある。し かしながら，これまでの多くの珪酸塩，ガラスの溶解実験では幅 広い $p H$ で実験がなされておらず, 多くの場合, ある $p H$ 值に対 寸る溶解速度定数が求められている。そこでここでは, まず既存 の実験による $k$ の推定と同様の方法で $k$ を求めた。

以上，溶解速度定数の推定について述べたが，珪酸塩鉱物の溶 解速度定数については, 詳しい点については鹿園 (1999) ${ }^{18)}$ を参 照されたい。

\section{$5 \cdot 3 p H$ に依存した溶解速度定数 $\left(k_{\mathrm{H}^{+}}, \mathrm{kOH}^{-}\right)$}

$\mathrm{CO}_{2}$ を地下に圧入すると地下水に溶け, 初期では $p H$ の低い地 下水ができる。この酸性の地下水は, 周りの岩石と反応し, $p H$ が上昇する。このように $\mathrm{CO}_{2}$ 地中貯留では $p H$ の異なる地下水と 岩石が反応寸るので, 鉱物の溶解速度定数の $p H$ 依存性を求める 必要がある。この溶解速度定数の $p H$ 依存の式は以下で表される。

$$
\frac{d C_{i}}{d t}=k_{H}+\left(\frac{A}{M}\right)\left[H^{+}\right]^{n H^{+}}+k_{O H-}\left(\frac{A}{M}\right)\left[O H^{-}\right]^{n O H-} \ldots \ldots
$$


そこで次に本実験結果をもとに $p H$ に依存した溶解速度定数 $\left(k_{\mathrm{H}^{+}}, k_{\mathrm{OH}^{-}}\right)$を求める。実験で求められた溶解速度定数 (対数) と $p H$ の関係を酸性側で直線として求める。その傾きは反応次数 $\left(\mathrm{n}_{\mathrm{H}}{ }^{+}\right)$であり, 接点が溶解速度定数 $\left(k_{\mathrm{H}^{+}}\right)$となる。同様にアルカ リ性でも行い, 反応次数 $\left(n_{\mathrm{OH}^{-}}\right)$と溶解速度定数 $\left(k_{\mathrm{OH}^{-}}\right)$を求める。 全試料で， $p H 5 \sim 9 の p H$ と溶解速度定数 $k$ はそれぞれ平均值を 求めプロットした。アルカリ性での接点は $p H$ に 14 を代入した 值となる。それぞれ求めた結果を Table 5 に示す。これより, 試 料 1,2 では $k_{\mathrm{H}^{+}}$の方が $k_{\mathrm{OH}^{-}}$よりやや大きい值を示し, 酸性条 件の方がアルカリ条件より溶解しやすいといえる。しかし，試料 3 は $k_{\mathrm{H}^{+}}$と $k_{\mathrm{OH}^{-}}{ }^{-}$で変わりがない。 $n_{\mathrm{H}^{+}}, n_{\mathrm{OH}^{-}}{ }^{-}$の值は, 試料 $1,2,3$ で変わりがなく,ほぼ $0.2(0.18 \sim 0.32)$ である。

\section{6. 結論}

(1) 玄武岩質岩石の初期溶解速度と長期溶解速度が大きく異な ること，および各種元素の溶解の時間依存性が異なることよ り, 玄武岩質岩石の溶解は $\mathrm{H}^{+}$イオンと $\mathrm{Ca}^{2+}, \mathrm{Mg}^{2+}, \mathrm{Na}^{+}$, $\mathrm{K}^{+}$イオンのイオン交換反応，次に $\mathrm{H}^{+}$と $\mathrm{Al}^{3+}$ のイオン交換 反応， Si-O 結合のブレーキングの順序でおこるといえる。

(2) 玄武岩質岩石の溶解速度定数の推定を行った。その結果, 立武岩質岩石の溶解速度定数 $\left(\log k\left[\mathrm{~mol} / \mathrm{m}^{2} \mathrm{~s}\right]\right)$ は, $p H$ 依存性 を示し, 酸性条件で大きく $p H$ が上がると小さくなり, 中性 条件で小さく, アルカリ条件で $p H$ が上がると大きくなるこ とが判明した。中性付近での長期溶解速度定数 ( 対数值) は $-11.2 \sim-11.7$ であった。この值は従来の值 $(-10.5)^{5)}$ より 1 桁程度小さい。

（3）初期溶解速度定数，長期溶解速度共に，試料により数倍程 度の違いはあるが, 有意な差があるとはいえず, 変質の程度, 組成の違いは溶解速度定数にあまり影響しないことが明らか になった。
Table 5 Dissolution rate constant $\left(k_{\mathrm{H}}{ }^{+}, k_{\mathrm{OH}}{ }^{-}\right)$and reaction coefficient $\left(n_{\mathrm{H}}{ }^{+}, n_{\mathrm{OH}}{ }^{-}\right)$determined based on the experiments of this study.

\begin{tabular}{l|c|c|c|c}
\hline Sample & $k_{\mathrm{H}^{+}}$ & $n_{\mathrm{H}^{+}}$ & $k_{\mathrm{OH}}{ }^{-}$ & $n_{\mathrm{OH}^{-}}$ \\
\hline Sample1 & -10.27 & 0.18 & -10.48 & 0.19 \\
\hline Sample2 & -9.87 & 0.21 & -10.36 & 0.19 \\
\hline Sample3 & -10.19 & 0.20 & -10.17 & 0.32 \\
\hline
\end{tabular}

謝辞本研究を進めるにあたり，柏木洋彦氏より有用なコメ ントを頂いた。ここに感謝致します。

\section{References}

1) S.Bachu: Energy Conversion and Management, 44 (2003), 3151-3175.

2) H. Kashiwagi and N. Shikazono: Journal of Ground Water, 47 (2003) , $65-80$

3) RITE $\mathrm{CO}_{2}$ Underground Sequestration Project, http://www.rite.or.jp/Japanese/project/ tityu/tityu.html

4) L. Marini: Geological Sequestration of Carbon Dioxide, Developments in Geochemistry, 11 (Elsevier, 2007)

5) C. Berger, C. Claparolos., C. Guy, and V. Daux: Geochim. Cosmochim. Acta, 58 4875-4886.

6) J.L.Crovisier: Material Research Society, 50 (1985), 273-280

7) J.L.Crovisier: Geochim. Cosmochim. Acta, 47 (1987), 377-387.

8) S.R.Gislason and H.P.Eugster: Geochim. Cosmochim. Acta, 51 (1987) , 2827-2840

9) S.R.Gislason, and E.H.Oelkers: Geochim.Cosmochim.Acta, 67 (2003) , 3817-3832.

10) V.Daux, C.Guy, T.Advocat, J.L.Crovisier, and P.Stille: Chemical Geol., 142 (1997) 109-126.

11) E.H.Oelkers, and S.R.Gislason: Geochim. Cosmochim. Acta, 65 (2001), 3671-3681

12) S.J.Gordon, and P.V.Bradu: Chemical Geol., 190 (2002), 113-122.

13) N.Spycher, K.Pruess, and J.Ennis-King: Geochim. Cosmochim. Acta, 67 (2003) 3015-3031.

14) L.L.Stillings, and S.L.Brantley: Geochim. Cosmochim. Acta, 59 (2005) , 1483-1496

15) S.R.Gislason, and E.H.Oelkers: Geochim.Cosmochim. Acta, 67, (2003), 3817-3832.

16) H.V.Sverdrup: The Kinetics of Base Cation Relase due to Chemical Weathering, (Lund Univ. Press, Sweden, 1990)

17) R.Shiraki and J.T.Iiyama: Geochim. Cosmochim. Acta, 54 (1990), 2923-2932.

18) N. Shikazono: Chemistry of Earth System, (University of Tokyo Press, 1997).

19) P.V.Brady and S.R.Gislason: Geochim. Cosmochim. Acta, 61 (1997), 965-973. 